\title{
Remembering a sociology of Human Rights ${ }^{1}$
}

\author{
Daniel Levy ${ }^{1}$ and Natan Sznaider ${ }^{2}$ \\ ${ }^{1}$ Department of Sociology, State University of New York at Stony Brook, Stony Brook, New York 11794-4356 \\ ${ }^{2}$ Academic College of Tel-Aviv-Yaffo, Israel, 2 Rabeno Yeruham St., ISRAEL \\ e-mail: daniel.levy@stonybrook.edu,natan@mta.ac.il
}

Submitted: 28 February 2014. Accepted: 31 October 2014

\begin{abstract}
A sociology of human rights sounds almost like a contradiction in terms. Sociology is about social groups, about particular experiences, about how people, embedded in space and time, make sense of their lives and give meaning to their world. It deals with power and interest and the social bases of our experiences. On the other hand, human rights are about human beings in general, without temporal or spatial references, not about groups and their boundaries. Human rights are about humanity, located in the world and connected to an inviolable nature. Global media representations, among others, create new cosmopolitan memories, providing new epistemological vantage points and emerging moral-political interdependencies. As such, memories of the Holocaust contribute to the creation of a common European cultural memory based on the abstract notion of human rights. Sociologically, a theory of human rights has to show how universal and particular memories co-exist, are reconciled etc. and what it means for the recognition of the "other", and the broadening of circles of solidarity.
\end{abstract}

KEYWORDS: Collective memory; holocaust; suffering; cosmopolitanism; vulnerability; universalism

Citation / Cómo citar este artículo: Levy, Daniel and Sznaider, Natan (2014). "Remembering a sociology of Human Rights". Culture \& History Digital Journal, 3(2): e013. doi: http://dx.doi.org/10.3989/chdj.2014.013

RESUMEN: Recordando una sociología de los derechos humanos.- Una sociología de los derechos humans suena casi como un oxímoron. La sociología se fija en los grupos sociales, en las experiencias particulares, y en cómo las personas, marcadas por el espacio y el tiempo, dan sentido a sus vidas y atribuyen un significado al mundo. Trata del poder, el interés y la base social de nuestras experiencias. Contrariamente, los derechos humanos se refieren a humanos en general, sin referencias temporales ni espaciales, y no a grupos y sus límites. Los derechos humanos tratan de la humanidad, ubicado en el mundo y conectado con su naturaleza inviolable. Representaciones mediáticas globales, entre otras, crean memorias cosmopólitas nuevas, disponiendo nuevos puntos de vista epistemológicos y interdependencias morales-políticas emergentes. Así, las memorias del Holocausto contribuyen a la creación de una memoria cultural europea común, basada en las nociones abstractas de los derechos humanos. Sociológicamente, una teoría de los derechos humanos tiene que mostrar cómo las memorias universales y particulares coexisten, se reconcilian etc. y qué significan para el reconocimiento del "otro" y la ampliación de los círculos de solidaridad.

PALABRAS CLAVE: Memoria colectiva; Holocausto; sufrimiento; cosmopolitismo; vulnerabilidad; universalismo

Copyright: (C) 2014 CSIC This is an open-access article distributed under the terms of the Creative Commons AttributionNon Commercial (by-nc) Spain 3.0 License. 


\section{THE TENSION BETWEEN SOCIOLOGY AND HUMAN RIGHTS}

A sociology of human rights sounds almost like a contradiction in terms. Sociology is about social groups, about particular experiences, about how people, embedded in space and time, make sense of their lives and give meaning to their world. It deals with power and interest and the social bases of our experiences. On the other hand, human rights are about human beings in general, without temporal or spatial references, not about groups and their boundaries. Human rights are about humanity, located in the world and connected to an inviolable nature. Rights and dignity come together and they travel without any kind of sociological clothing. Human rights have turned into questions of belief and contain the aura of the sacred. It is, therefore, a challenge to construct a sociological analysis of human rights without reducing them to power struggles or the politics of interest.

To avoid, what we think is a misleading dichotomy, we demonstrate how, once institutionalized, human rights norms themselves constitute political interests shaping power balances and the relationship between universal identifications and particular identities. Our central claim is that the social embeddedness of human rights is connected to memories of catastrophes, more specifically, the changing representations of the extermination of the Jewish people during the Holocaust. It was this particular experience that became the universal mirror onto which the precarious vulnerability of human beings has been projected. Our sociology of human rights shows how this universalization operates through different forms of remembrance. Through the analytic prism of historical memories - which refers to shared understandings specific pasts carry for present concerns of a political community- we provide an explanation for both the salience of human rights norms as a globally available repertoire of legitimate claim making and the persistence of particular identities. Paradoxically, as we will show, when memories of the Holocaust become enshrined in commemorative practices treating them as the paradigmatic violation of human rights, it is likely to reinforce a split between universal and particular modes of identification.

An early attempt to construct a sociology of human rights that recognizes the precarious relationship of particular (i.e. national) citizenship and universal (i.e. global) human rights can be found in Hannah Arendt's The Origins of Totalitarianism. Published in 1951, the book was written under the impact of the Jewish catastrophe several years earlier. In a chapter entitled "The Perplexities of the Rights of Men", Arendt reflects on the particular Jewish experience of political homelessness and ends her criticism with a reflection on universal human and citizen rights. Looking from the Jewish experience inside out, she addresses one of the key questions of our times: questions of minorities and citizenship. On the one hand, she sees the constant constitution of ever new minorities in ethnically homogenous nation-states and therefore, citizenship based on nationality as an ever widening gap of a universal claim to humanity and human rights. Arendt leans on Edmund Burke who had nothing but ridicule for abstract human rights, privileging the rights of Englishmen. For Arendt this means that without institutional and state protection, universal rights are just empty words, naked like human beings without citizenship and state protection. Men cannot appeal to other men as men, but only as members of communities. This is her sociological insight into the abstractedness of human rights (Ignatieff, 2001). Her interest in the Jewish fate in modernity was also a measuring stick for the fate of man in modernity as such. Arendt exposed the limits of an abstract universalism, pointing to the necessity to embed and endow human rights with institutional powers. The dilemma that Arendt directs our attention to circumscribes the dilemma of a social theory of human rights. It is the dilemma between the sincerity of the declarations that human beings are endowed with universal human rights and the situation of the rightless themselves. "Abstract", "universal" and "human" are therefore empty terms in a world where people are being deprived of the protection of the state. Arendt brought the problem of human rights back to its political backbone: enforcement. And enforcement is about the social and political foundations of human rights and not about power interests alone (Isaac, 1996, 2002).

The foundations of human rights have changed considerably since the end of the Cold War and in the context of global interdependencies. During the last six decades numerous challenges to the particularistic presuppositions that inform the dispensation of rights based on national belonging have been observed. "With the erosion of national citizenship, Marshall's three forms of rights (legal, political and social) have been augmented by rights that are global, namely environmental, aboriginal and cultural rights" (Turner, 2001: 189). Human rights as a global issue are, of course, not a new phenomenon. Its origins can be traced back to the late $18^{\text {th }}$ century and the international formalization starting in the late $19^{\text {th }}$ century. Its beginnings are "marked by attempts to extend the processes of delimiting public power to the international sphere, and by attempts thereafter to transform the meaning of legitimate political authority from effective control to the maintenance of basic standards or values, which no political agent, whether a representative of a government or state, should, in principle, be able to abrogate" (Held, 2003: 165). Elsewhere we have examined the impact of the Human Rights Regime on the transformation of state sovereignty (Levy and Sznaider, 2006). Suffice to say here that aggressive militarism has been replaced by a codification and legal standardization of warfare. The reason for this is partly because the sanctity of the nation state has been lifted and both individuals and (ethnic) minorities have obtained a stronger legal status under the aegis of transnational jurisdiction. The modern Human Rights Regime is premised on the notion that the prevention of human suffering takes precedence over the principle of sovereignty (Dunne and Wheeler, 1999; Ignatieff, 2001) even if that prevention of suffering may clash with 
the state's calling of providing security for its citizens alone.

This "human rights turn" and the concomitant transformation of nation-state sovereignty, we suggest, raises new questions about the Hobbesian quid pro quo of freedom and protection. Following Hobbes, people's appreciation of the security the state can provide is a direct function of how insecure they feel. Fear of violent death and the desire for self-preservation lead to the acceptance of the Leviathan as the ultimate protector, essentially providing the reasoning behind the legitimacy of modern state sovereignty. The Human Rights Regime too seeks to liberate us from the fear of violent death. Both, the Leviathan and the legitimating power of the Human Rights Regime are predicated on their ability to inspire a fear of punishment and violation. Hobbes accomplishes this with references to a "state of nature" that is characterized by anarchy and a war of all against all. It conjures up an imagery of "violent death", that ultimately explains the delegation of legitimate authority to the state in return for protection. While Hobbes' state of nature is a pre-historical construct and asks of people to forget their desire for immortality, memories of the Holocaust function as the historical reference point for what happens when states turn from being protectors to violators. Here people are not only mortal but can be disposed of at the will of a brutal and sovereign state.

The prevalence of memories of state sponsored human rights violations and their legal inscription in the global age are challenging the foundational Hobbesian contract. The Holocaust underscores that the state does not provide security and in some cases the Leviathan can become the biggest executioner of them all. People obey the state because of a fear of violent death that supersedes the fear of the state. After 1945, at least in the European context, memories of chaos and civil war and the constant fear of the potential for violent death have become the source for shifting some legitimacy to nation-transcending, i.e. human rights principles. Alternative conceptions of (citizenship) rights have emerged that challenge the national premises of solidarity, long cultivated through memories of war and blood. It has been replaced by the global market, consumption and mutual indifference (Sznaider, 2000).

Elsewhere we have described the ascendance of a $\mathrm{Hu}-$ man Rights Regime as a Leviathan writ large (Levy and Sznaider, 2004). Unlike Hobbes' imaginary state of nature, the human rights narrative is based on concrete historical references. But like Hobbes, it ultimately tilts toward an abstract historical scenario that is less about the actual abuses than about a new illusion of protection. There is no "space" for "barbarous acts" to be treated as "normal" occurrences and become part, of say, the daily news. Here the commemoration of the Holocaust as a universal code for human rights abuses ultimately is about forgetting the particular experience and redirecting the focus on symbolic, political and cultural practices that underscore the "solution" offered by the Human Rights Regime rather than engaging with the "problem" in con- crete fashion. Here too, it is the unbearable coping with particular forms of violations and violence that has to make room for our desire for security and protection. In other words, the politics of memory assumes a similar ahistorical dimension that Hobbes' state of nature is predicated on.

It is this fragile contract that explains the conditionality of the Human Rights Regime. The transformations of warfare and terrorism, among other things, can explain these new developments and throws the state back to its founding moment: the provision of security for its citizens. As we will show in our concluding section, new security threats, the breakdown of states and other developments operate as stark reminders for the precarious nature of the Human Rights Regime. In what follows we specify the conditions under which the balance between particular identities and universal identifications is shaped. By extension the salience of human rights norms is a function of how abstract memories of violations and particular memories, as well as fears of violent death, are contending with each other.

\section{THEORIZING HUMAN RIGHTS}

Does this dichotomy ultimately mean that a social analysis of human rights is a contradiction in terms? Is that the reason that by and large, sociologists have avoided the subject of human rights in theoretical terms? A brief and schematic look at the causes of this lacuna is instructive. In general terms, sociological thinking counters the belief that politics should be guided by theoretical doctrine and universal principles and appeals to abstract rights. On the other hand, it is exactly this kind of metaphysical zeal rejected by sociological thinking, which is at the heart of the contemporary project for a global $\mathrm{Hu}-$ man Rights Regime. The conceptual dearth is, primarily, the result of the national caging that coincided with the birth of sociology and remains the hallmark of social theory. This national focus is compounded by the aforementioned Hobbesian social contract between a collectivity and a sovereign. Since the protection of a particular community has primacy, there is little conceptual and political space left for a nation-transcending universal approach. One could even argue that this national container is endemic to the broader sociological enterprise. Sociology is about exclusion and inclusions, i.e. about social groups and solidarity of which the nation is a prominent category. As such, it is mainly about the definition of group boundaries, with manifestations such as communitarianism and ethno-nationalism on the far end. In contrast, human rights are about the breakdown and abolishment of boundaries. It is about humans and not about embedded people in communities. It suggests a cosmopolitan solidarity not based on communal allegiance.

In the history of political thought, it is the difference between Kant and Rousseau. A universal Human Rights Regime is no longer the "General Will" of modern democracy, as mapped by Rousseau onto the nation and woven into the sociological theories of Durkheim and We- 
ber. Rousseau's General Will was not only the foundation of modern relativism; it is also the source for the modern idea of the nation not merely as a collection of followers, but as the institution that reconciled freedom and determinism. It was the birth of society as national society. In the course of the $20^{\text {th }}$ century, the "general" has become synonymous with the universal, and that universal is largely considered to be the nation. This is how methodological nationalism and universalism are tied up in sociological theory, excluding the universality of human rights from its consideration and pushed into the realm of normative philosophical analysis.

Furthermore, "the analysis of human rights presents a problem for sociology, in which cultural relativism and the fact-value distinction have largely destroyed the classical tradition of the natural-law basis for rights discourse" (Turner, 1993: 489). Sociology is about causality and about historicism. Natural law is the opposite by claiming that there is a firm foundation in nature for rights and that they are not subject to choice (Strauss, 1955). Another tension revolves around the notion that sociology is about interests (material and ideal), whereas human rights, at least in its self-presentation, are universal and void of particular interests. This disparity is often rearticulated when sociologists seek to debunk the universality of human rights by referring to it as a new form of imperialism and a threat to particular cultural values (Chomsky, 2005; Evans, 2001; Waters, 1996). Lastly, as we shall illustrate in a section addressing a "clash of memories", the incorporation of the universal (and unconditional) essence of human rights into this national cage is frequently circumscribed by a host of conditions that involve contentious relations. Especially violent conflicts raising levels of threats and fears tend to reinforce the centrality of the Leviathan and the protection of a particular community.

Given the prevalence of national assumptions that inform most conceptualizations of (citizenship) rights, a social theory of human rights beyond the national container has yet to be constructed. Bryan Turner's pioneering work on human rights $(1993,1997,2006)$ is an important step in this direction. According to Turner, "vulnerability defines our humanity and is presented here as the common basis of human rights" (2006: 1). Our ontological security, negated through our awareness of universal human frailty, is a major causal factor for the increasing dominance of human rights consciousness. However, this hardly suffices to ensure the equal enforcement of such broadly defined rights. They require social institutions, which themselves are "fragile and precarious, and there is a complex interaction between our human frailty, institution building, and political or state power" (Turner, 2006: 1). Turner recognizes that the balance between universal and particular commitments can, but need not necessarily be mutually exclusive. He argues "that the protection offered by nation-states and national citizenship is declining, and yet the state and citizenship remain important for the enforcement of both social and human rights" (Turner, 2006: 2). Realizing the impact of globalization, Turner suggests a sociology of rights that concedes the limitations of bound- ed citizenship conceptions. Social rights of nation-states are being replaced or augmented by human rights answering to new global conditions (Soysal, 1994). Vulnerability becomes in this view the new global condition mediated by constant access to the sights of suffering people across the world (Boltanski, 1999; Tester, 1999). People become witnesses to human rights violations. If human rights come to be understood as violations of rights based on the commonness of our vulnerability people will "feel" that they are defending the foundations of their own vulnerable identities when they defend the importance of human rights for foreigners and strangers. The cultural and political diversity that is essential to this kind of life has been slowly elevated to a central political norm. It sometimes seems as if it were even more highly valued than the particular principle of exclusivity with which it now shares conceptual and political space.

This relates to a central debate in political theory: the human rights versus popular sovereignty split (Benhabib, 2006). Rather than addressing them as mutually exclusive categories, we have sociologized this tension by showing how the adherence to human rights has become a core legitimating principle of sovereignty itself (Levy and Sznaider, 2006). The normative orientation of political theorists seeks to mediate between democracy (popular sovereignty) and liberalism (human rights). Though this mediation, beyond the theoretical claim that the combination of it is rational and therefore universally valid (Habermas, 2006), remains problematic in practice. Rationality, be it as a foundational or communicative category, even if enjoying a growing diffusion, also entails a reaction that denies its primacy. Fundamentalism, after all, is not an anachronism or a return to an imagined past, but largely a modern and increasingly global reaction to the success of rationality. Turner's move from spirit to body is a sociological attempt to get out of this intellectual quagmire.

\section{MEMORIES OF HUMAN RIGHTS}

In this essay we expand on Turner's theory by suggesting a focus on, how memories of human rights abuses and failures to address them have shaped both the formation of a universal Human Rights Regime and the reconfiguration of particular identities and state practices. Our mnemonic approach provides a conceptual framework for examining the balance between universal identifications and particular identities in a global context. Rather than treating the universal and particular as mutually exclusive categories either politically or morally, we suggest that they are intricately (and inevitably) linked. Both the universal and the particular are social categories. Through the analytic prism of memories of rights abuses we provide an explanation for the salience of human rights norms as a globally available repertoire of legitimate claim making. Public negotiations about memories of failures to address past human rights abuses (e.g. legislative measures, historical revisionism, educational measures, and commemorative practices) reveal the balance of 
particular and universal identifications. Tracing public controversies about human rights abuses and their commemorative expressions during the last six decades, we demonstrate how this awareness about bodily frailty and its concomitant institutionalization into a Human Rights Regime is mediated by who remembers what and how memories of past abuses change. At the same time, we show how this process is continuously challenged by a set of competing values in which universal and particular memories vie for normative primacy.

Accounting for the global context and the interaction with the local (i.e. national) within which negotiations about memories are shaped nowadays, we propose a cosmopolitan methodology (Beck and Sznaider, 2006). Methodological cosmopolitanism points to a new research program that, first and foremost, aims to overcome the aforementioned methodological nationalism (Beck, 2002). It establishes a kind of "methodological scepticism" as a vector of research for opening up concepts and methodological principles of modern sociology, most notably regarding the nation-state as the axiomatic unit of analysis. Furthermore, methodological cosmopolitanism challenges a series of modernist dualisms, while providing interactive mechanisms for analysing the balance of the universal and the particular. In fact, cosmopolitan methodology defines cosmopolitanization itself as made up of the continuous dialectic between the local and the global. In this sense, it not only implies the recognition of both endogenous and exogenous factors, but also acknowledges that it is the interaction between the two, rather than just the internalization of exogenous pressures, which produces new meaningful frameworks.

Accordingly, cosmopolitan memories refer to practices that shift attention away from the territorialized nationstate framework, which is commonly associated with the notion of collective memory (Levy and Sznaider, 2001, 2005). Rather than presuppose the congruity of nation, territory and polity, cosmopolitan memories are based on and contribute to nation-transcending idioms, spanning territorial and national borders. The classical concept of collective memory is group and nation bound (Halbwachs, 1980). We argue that this "national and group container" is slowly being cracked. Whereas universalism frequently implies the dissolution of the particular, the cosmopolitan gaze provides an analytic lens that shows how particular national and ethnic memories are not erased but transformed. Conceptually speaking then, cosmopolitan memories provide a crucial resource for explaining the significance of human rights norms as a globally available political repertoire as well as shaping the practices through which the balance between universal and particular identifications are negotiated.

Our cosmopolitan methodology approaches the notion of an international convergence of rights policies and universalization with some reservations. For one, it is important to distinguish our cosmopolitan approach from the strong international impulses that contributed to the original institutional manifestations of human rights at the end of the $19^{\text {th }}$ century. Lasting until the beginning of
World War II, this period witnessed a significant growth in international organizations and laws dedicated to human rights. It should be pointed out, though, that this internationalist era was primarily geared toward the consolidation of nation-state sovereignty. In contrast, the cosmopolitanization of the last two decades indicates a re-casting of the state-society-nation relationship. While the "old internationalism" regulated the relations between nation-states and sanctified their particularism, the "new cosmopolitanism" challenges the primacy of the nation and emphasizes the universal foundations of global interdependencies.

Our mnemographic approach serves as another corrective to expectations of convergence. Structural similarities do not necessarily determine the meanings attached to human rights norms in particular national contexts. As we have pointed out above, cosmopolitan memories co-exist with memories of communal losses and traumata. In our discussion section below, we show how reactions against the very universality of human rights have become an important feature of how particular identities are being negotiated. Thus, rather than treating national sentiments and other expressions of particular identification as anachronistic, we show how they are addressed in a new context of global interdependencies and related "clashes of memories". Collectivities remember their vulnerabilities in different ways, diachronically but also cross-culturally. In light of such dis-simultaneities, antagonisms persist and depending on resulting threats and fears, they cannot be reconciled with recourse to rationality or universality. In short, a plurality of memories about human frailty and accompanying rights are constitutive for the political and cultural salience of human rights. And a theory of human rights must reckon with these plural and sometimes fragmented memories. Such a theory is not only about convergence and universalism, but also about differences expressed in communal memories and continuing antagonisms. However, in contrast to the first half of the $20^{\text {th }}$ century and until the dissolution of the bi-polar world, these tensions and the accompanying clashes of memories now unfold on the background of a cosmopolitan ideal that, while most prominent in Europe, has become a global norm against which particularism is articulated.

Cosmopolitan memories then shape the balance between universal and particular rights discourses in the context of numerous processes: One refers to the political will of states to engage with memories of rights abuses and the extent to which it is becoming a prerequisite for their legitimate standing in the international community and increasingly also a domestic source of legitimacy. Operating with neo-institutionalist assumptions, the world society approach demonstrates how global norms become internalized and assume modular capacities, circumscribing the activities of national policy makers (Meyer et al., 1997; Boli and Thomas, 1997). Accordingly, the Human Rights Regime creates isomorphic pressures on nationstates leading them to join international human rights treaties (Hafner-Burton and Tsutsui, 2005). Two, in democrat- 
ic countries, the violation of human rights has frequently mobilized significant opposition and incurred political costs. Another source of friction between the particular and the universal relates to the aforementioned Hobbesian contract, informing the balance of state-security and society. Three, legal inscriptions of memories of human rights abuses do recast the underpinnings of International Law itself and also constitute significant precedents for the cosmopolitanization of national jurisdiction. Elsewhere we have examined the development of a new global legalism driven by human rights norms and its implication for the reconfiguration of sovereignty (Levy and Sznaider, 2006).

As we will illustrate in our final discussion section, this tenuous relationship is often the result of political contingencies. However, we argue, that this tension is not merely epiphenomenal, but integral to how memories of human rights operate. The salience of universal (human) or particular (national) rights is mediated by, among other things, the extent to which memories of past human rights abuses are transmitted as concrete or abstract forms, the latter proliferating with the cosmopolitanization of memories. Human rights matter only to the extent that their universality is recognized. This recognition, in turn, is predicated on a process of de-contextualization by which memories of concrete (particular) atrocities are transformed into abstract (universal) violations of humanity. Without this de-contextualization it is difficult to re-contextualize memories of human rights as abstract categories and thus ensure their recognition as universal lessons for humanity.

Moreover, this process of abstraction does little to change the fact that communities carry different memories of the past, based largely on the extent to which memories of past abuses are a concrete part of shared experiences or whether they are lacking the kind of proximity that allow them to become abstract principles. Accordingly, the strength of human rights principles in a given national context is the product of the tenuous balance of particular (concrete) and universal (de-contextualized) memories. The latter are in essence a form of forgetting. The relationship of memory and forgetting has received significant attention in literature (Ricoeur, 1999). However, contrary to most views, we are not treating memory as an antidote to forgetting. Nor are we merely saying that memory can facilitate forgetting or that they are two sides of the same coin. Instead, we are suggesting that institutionalized memories of human rights abuses, inexorably implies forgetting. The institutionalization of such memories and thus their ability to mobilize legitimate political claims is largely based on the aforementioned process of de-contextualization, which in turn requires a shift from concrete memories to abstract remembrance. That is, a move away from the concrete (i.e. particular) experience toward a more abstract (i.e. universal) message. Consequently, we observe a shift consisting of the institutionalization of the remembrance of barbarous acts at the expense of memories of the barbarity of the acts.

The distinction between memory and remembrance then is not incidental. Nor can it be reduced to the so- called instrumentalization of memories. Memory vacillating between the concrete and the abstract, and the implied de-contextualization, can be related to three dimensions. It inheres in the course of action that gives memories their ritualistic strength. Ritualization depends on mediation, which by definition requires a certain form of abstraction. Considering the various media through which memories of past human abuses are communicated, we consider this to be a process of mediated forgetting. Failure to remember is also implied insofar as proximity to that which is remembered will shape the relative political-cultural significance it carries for a community. Put differently, the universality of human rights necessitates a certain distance from the actual events that are being remembered.

Lastly, the immanence of this dynamic is not just the product of historical and geographic proximity, but also the result of temporal distance to the events that are being remembered. This temporal distance is captured in Jan Assmann's distinction between communicative and cultural memory (Assmann, 1991). Communicative memory refers to memory based on group-specific carriers and is expressed through the daily encounter and stories of people involved in the events that are being remembered. Cultural memory exists independent of its carriers and is reproduced through media and commemorative institutions. "What is at stake, is the transformation of communicative, i.e. lived and in witnesses embodied memory, into cultural, i.e. institutionally shaped and sustained memory, that is, into "cultural mnemotechnique"" (Assmann, 1991: 343). This transition corresponds to our argument about the inevitable shift from the concrete to the abstract. Cultural memory turns history into narrative and shifts attention from fact-driven (i.e. particular) history to remembered history (i.e. produced through ritualization and other forms of representation).

This nexus of time changes and the need for representational mechanisms is also acknowledged in the work of the French sociologist Maurice Halbwachs, a foundational figure in the field of collective memory studies. Halbwachs (1980) makes a distinction between social memory and historical memory. Social memory is the memory of things both that one has experienced personally, and that the group that one is a part of has experienced. It is history before it becomes history: the present experienced through a group and then remembered. Historical memory, on the other hand, is mediated like Assmann's conception of cultural memory by films and books and schools and holidays. These analytic distinctions underscore the difference between memory and remembrance, on the one, and the concomitant process of abstraction, on the other.

\section{CLASH OF MEMORIES}

One way of looking at this phenomenon empirically is to focus on the de-contextualization of memories of human rights abuses, which functions as a prerequisite for the spread of human rights as a universally recognized idiom. The de-contextualization of particular memories of human rights abuses and their universal re-appropria- 
tion can be addressed by distinguishing between "who" is remembering and "what" is remembered. Moreover, cosmopolitan memories of human rights abuses are circumscribed by the historical occurrence of a forgiveness narrative that has further contributed to the shift from memory to remembrance and a corresponding transition from concrete individual to more abstract collective dimensions. Memories of human rights violations have become a subject of public negotiations and subjected to the imperatives of forgiveness and reconciliation.

We would like to briefly illustrate these dynamics by looking at how changing memories of the Holocaust have played a seminal role for the emergence of a human rights discourse. Elsewhere we have focused on the historical dimensions of this process (Levy and Sznaider, 2004, 2006). Here our intent is more conceptual, as we examine how changing perceptions of Holocaust memory are contributing to the abstraction that inheres in the unconditional demands of human rights claims. A first inclination would be to ask whether the Holocaust can be remembered outside the ethnic and national boundaries of the Jewish victims and the German perpetrators. A closer look reveals that this particular relationship has been transposed into a universal discourse where historical memories are the main mechanism through which particular experiences are being universalized and ultimately de-historicized. This also involves different questions for the future of those remembering groups. When the Holocaust is remembered within the ethnic boundaries of its Jewish victims, the question which is asked is "Why did this happen to us" and the frame of reference is anti-Semitism. When the Holocaust is commemorated outside the victim group, the central question is "How could it happen at all" and is framed with general references to racism and genocidal practices. It is precisely the abstract nature of "good and evil" that symbolizes the Holocaust, which contributes to the extra-territorial and ultimately de-contextualized quality of cosmopolitan memory, thus setting the stage for abstraction. ${ }^{2}$

Paradoxically, this process of de-contextualization has its origins in a setting that was actually the first opportunity to offer detailed insights into the murderous details of the German extermination machine, namely the War Crime Tribunals of the Allied Forces against former Nazis. Together with the UN Conventions of Human Rights and Genocide at the end of the 1940s, they sat the stage for rendering a particular historical event into a universal code (Alexander, 2002). It was the American understanding of the Holocaust, which framed the Nuremberg Trials, which de-emphasized the particular experience of Jewish victims: Nazi war crimes happened to 60 million people, among them 6 million Jews. During the Nuremberg trials, the Holocaust appeared as a set of facts but not yet as an idea. But, surprisingly perhaps, all the essential facts were there from the beginning, starting with the estimate that 5.7 million Jews had been killed by an intentional plan of the Nazi high command. There was also visual evidence when the film The Nazi Concentration Camps was screened, providing one of the most dramatic moments in the trial. But the crimes against the Jews took up a tiny percentage of the total Nuremberg indictment, and the Jews themselves remained abstract victims. Thus, for example, no victims were testifying on their behalf. Yet, even if the Holocaust and the fate of the Jews remained a neglected aspect of the Nuremberg trial, it did provide the backdrop for its universalistic message. The realization of the horrors of the Nazi atrocities and the Holocaust informed the scope of universal human rights jurisdiction. The struggle at Nuremberg was conceived as one between civilization and barbarism. Civilization was the victim, Nazi barbarism the perpetrator. And this is how we initially got from the Holocaust to the concepts of "humanity" and of "crimes" against them. The Jews were there, but they were standing in for "humanity as a whole".

It is against a background of particular national narratives and the normative universal imperative of reconciliation as response to human rights violations, that the dualism between victim and perpetrator memories is organized and ultimately fades. The vanishing of concrete personal memories is accelerated through the Americanization of Holocaust representations. ${ }^{3}$ As a result, we observe the displacement of the dichotomy of perpetrators and victims and the appearance of a third epistemological vantage point: that of the passive by-stander and an attendant witness perspective.

This abstraction is also the prerequisite for its legal inscription into a principal conception of International Law. Tensions between individuality and collectivity are mirrored in the emerging legislative language of international law, especially pertaining to crimes against humanity (Levy and Sznaider, 2006). The individual autonomy is taken away from victims of genocide and other atrocities where people are targeted because of their group (i.e. not individual) characteristics. Ironically, subsequent attempts to redeem their individuality also involve a collective approach (i.e. class action suits which place the emphasis on that which is collective and categorical). This in turn leads to the recognition of the individual and the abstraction of the crimes and the ensuing processes.

At this point, the Holocaust has been reconfigured as a de-contextualized event. Memories of the Holocaust shape the articulation of a new rights culture. Once this new rights culture is in place, it no longer needs to rely on its original articulation (in this case the memory of the Holocaust) but it assumes strong normative powers. Holocaust memory and the new rights culture are, in other words, mutually constitutive. To be sure, this is not by necessity but is the result of particular historical conjunctures (the end of the Cold War, the Balkan wars of the 1990s, as well as the repeated failures of this new Human Rights Regime to prevent acts of ethnic cleansing and genocide). The term Holocaust has passed from an abstract universal, to a set of very particularistic and/or national meanings, back to what we have elsewhere referred to as cosmopolitan memories. The Holocaust is now a concept that has been dislocated from space and time precisely because it can be used to dramatize any act of injustice, racism, or crime perpetrated anywhere on the planet. 


\section{THE RETURN OF THE NEW LEVIATHAN}

If the early 1990s gave rise to a surge in both the institutionalization of a Human Rights Regime and academic attention to it, by the end of the millennium, and even more so after September 11, 2001, human rights were perceived to be in a crisis (Ignatieff, 1999; Calhoun et al., 2002). Most of these commentaries were premised on the assumption that the relationship between Realpolitik and human rights was a zero-sum game. In this essay we have demonstrated how the vicissitudes of the Human Rights Regime have become an integral part of politics, thus complicating such a dichotomous approach to human rights and politics. The contentious relation between the two, rather than being predicated on mutual exclusiveness, we suggest, is mediated by, among other factors, competing memories and different political situations.

Given the immanent tension between the absolute and unconditional demands of human rights principles and the conditionality of politics, human rights activists, lawyers and others perceive them as an absolutist framework whose principles admit no compromise. At the same time, it provides a set of standards against which all governments can be measured. It is precisely the prominence of human rights as a legitimating principle and the recognition that states frequently do not meet its requirements, that challenges the ongoing debate between so-called realists and idealists among International Relations scholars. As adherence (or lack thereof) to the Human Rights Regime confers legitimacy on states (or reduces it), politics and human rights seem less at odds then the realistidealist divide would suggest. Conversely, the absolute nature of human rights too can (and is) subjected to compromise and adjustments depending on particular political requirements.

A prominent example for how human rights and politics are balanced emerges in the context of transitional justice. Here the question shifts from a quest for absolute justice to one in which states look for the best outcome possible at a given time and in light of available resources. With "best" being measured against the alternatives, and not in terms of how far they fall short of an absolute human rights conception. Here the unconditional nature of human rights is weighed against the requirement to provide peace and stability. This could be one of the fundamental reasons why successor governments and bureaucracies are usually relying on some continuity and pre-existing elements. This last group must by definition be small or the operation cannot possibly be accomplished in a limited period of time. Thus, at times, amnesties appear as the right political choice. Looking again at one of the defining examples, the de facto amnesty granted to Nazi officials after the war cannot possibly be squared with the demands of justice, and of course, always looms in the background of such processes. Again, this needs to be decided case by case. Adam Michnik and his fellow activists, who engendered the transformation in Poland, operated with the slogan "Amnesty Yes. Amnesia No" (Michnik and Havel, 1993). Current debates in
Latin America about the acceptable balance of memory and prosecution are ultimately decided under the requirements of social and political stability. Conversely the deBathification of Iraq has turned out to be a political liability. Amnesties will always contain groups and members of the former regime that are seriously tainted in human rights terms. And this is also, where forgiveness as a political principle may come in. A human rights framework that knows no compromise or that sees any trade-off as a damnable dilution of its principles is completely unsuited to apply such a strategy. This is especially important in ethnic struggles all over the globe today.

Ultimately we see how human rights principles can be subjected to particular requirements. Judging by the multitude of experiences in different parts of the world, global discourse about forgiveness and human rights does not seem to be based on an absolute universalistic ethic. It is the product of negotiations with the respective other. Rwanda is a case in point. It shows that even an internationally established tribunal, such as the International Criminal Tribunal for Rwanda, recognizes the need to adjust to local jurisprudence, as is evidenced in recognizing the decision of the Rwandan's government to work together with civil society on the implementation of the informal "gacaca" courts. In other words, it is not a universal morality, but instead we are witnesses to a global genesis of conditions of forgiveness that are shaped through the dialogue with the local. It is, often times, an ad-hoc conception of justice that incorporates a globalized human rights culture into respective local and particular negotiations.

A social theory of human rights, therefore, has to take into account the problem of the right mixture between what Max Weber called "Verantwortungsethik" (ethics of responsibility) and "Gesinnungsethik" (ethics of ultimate ends). Forgiveness might actually be a bridge between the two worlds of communal solidarity and universal human rights. Could it be that states after transitions will grant amnesties and forgive political criminals in the name of peace and stability? Should we allow these decisions to be overturned by an international tribunal? Here one faces the fundamental Hobbesian situation, where civil peace is often more important than morality (human rights) - where it is often the only precondition that would make real morality possible. This is fundamentally the opposite perspective to that of an absolute framework of human rights, which essentially assumes civil peace can never be endangered by its activities -that any amount of mobilization, polarization and anathematization will never bring about a complete breakdown of the state but always only purify it. The ultimate reality of the situation is the need for peace- which means the realities of power. And this is why we need flexible principles, whose essence is to find the best solution given the limits of the situation and the possibilities at any point of making things worse or not lasting. These principles are designed to lead to the best compromise. They are the right principles to guide our choices even when we are trying to reach humanitarian goals, i.e., a society in which people 
live better, safer, freer, less fearful lives. They are the right principles to organize our thought on such matters. Human right principles, which are designed not to compromise, may be not.

\section{NOTES}

1. The authors appear in alphabetical order. Please direct all correspondence to Natan Sznaider (natan@mta.ac.il) at the Academic College of Tel-Aviv-Yaffo, Israel.

2. We are, of course, aware that the relevance of Holocaust memories are highly contingent. And as much as memories of the Holocaust are an attempt to articulate a foundational European moment, they have frequently operated as a divide between Western-Europe and Stalinist experiences behind the Iron Curtain. These politics of memory are persisting in the East. We address these politics of memory in a chapter entitled "East meets West: Europe and its Others" in our book Human Rights and Memory (2010).

3 . The proliferation of personal memoirs during the last two decades does not contradict this process, since for the most part these kinds of individual memories are now read (and written) within a broader framework of reconciliation. Especially retroactive accounts tend to share narrative patterns with their counterparts in popular media.

\section{REFERENCES}

Alexander, Jeffrey (2002) "On the Social Construction of Moral Universals: The 'Holocaust' from War Crime to Trauma Drama". European Journal of Social Theory, 5 (1): 5-85.

Arendt, Hannah ([1951], 2004) The Origins of Totalitarianism. Schocken Books, New York.

Assmann, Jan (1991) "Die Katastrophe des Vergessen. Das Deuteronomium als Paradigma kultureller Mnemotechnik". In Mnemosyne. Formen und Funktionen der kulturellen Erinnerung, edited by Assmann, Aleida and Harth, Dietrich. Fischer, Frankfurt, 337-55.

Barkan, Elazar and Karn, Alexander (2006) Taking Wrongs Seriously: Apologies and Reconciliation. Stanford University Press, Stanford.

Beck, Ulrich (2002) "The Cosmopolitan Society and its Enemies". Theory, Culture \& Society, 19 (1-2): 17-44.

Beck, Ulrich and Sznaider, Natan (2006) "Unpacking cosmopolitanism for the social sciences: a research agenda". British Journal of Sociology, 57(1): 1-23.

Benhabib, Seyla (2006) Another Cosmopolitanism: Hospitality, Sovereignty, and Democratic Iterations. Oxford University Press, New York.

Boli, John and Thomas, George M. (1997) "World Culture in the World Polity: A Century of International Non-Governmental Organization". American Sociological Review, 62(2): 171-190.

Boltanski, Luc (1999) Distant Suffering. Cambridge University Press, Cambridge.

Calhoun, Craig; Price, Paul and Timmer, Ashley (editors), (2002) Understanding September 11. The New Press, New York.

Chomsky, Noam (2005) Imperial Ambitions: Conversations on the Post-9/11 World. Metropolitan Books, New York.

Dunne, Tim and Wheeler, Nicholas J. (editors), (1999) Human Rights in Global Politics. Cambridge University Press, Cambridge.
Evans, Tony (2001) The Politics of Human Rights. Pluto Press, London.

Habermas, Jürgen (2006) The Divided West. Polity Press, London.

Halbwachs, Maurice (1980) The Collective Memory. Harper and Row, New York.

Hafner-Burton, Emily and Tsutsui, Kiyoteru (2005) "Human Rights in a Globalizing World: The Paradox of Empty Promises". American Journal of Sociology, 10 (5): 1373-1411.

Held, David (2003) "The Changing Structure of International Law: Sovereignty Transformed?". In The Global Transformations Reader, edited by Held, D. and McGrew, A.. Polity Press, London, 162-176.

Hobbes, Thomas ([1668], 1982) Leviathan. Penguin Classics, New York.

Ignatieff, Michael (2001) Human Rights as Politics and Idolatry. Princeton University Press, Princeton.

Ignatieff, Michael (1999) "Human Rights: The Midlife Crisis". New York Review of Books, 20th May.

Isaac, Jeffrey (1996) "A New Guarantee on Earth: Hannah Arendt on Human Dignity and the Politics of Human Rights". American Political Science Review, 90 (1): 61-73.

Isaac, Jeffrey (2002) "Hannah Arendt on Human Rights and the Limits of Exposure, or Why Noam Chomsky Is Wrong about the Meaning of Kosovo". Social Research, 69 (2): 263-295.

Levy, Daniel and Sznaider, Natan (2002) "Memory Unbound: The Holocaust and the Formation of Cosmopolitan Memory". European Journal of Social Theory 5 (1): 87-106.

Levy, Daniel and Sznaider, Natan (2005) Memory and the Holocaust in the Global Age. Temple University Press, Philadelphia.

Levy, Daniel and Sznaider, Natan (2006) "Sovereignty transformed: a sociology of human rights". British Journal of Sociology, 57 (4): 657-676.

Levy, Daniel and Sznaider, Natan (2010) Human Rights and Memory. Penn State University Press, University Park.

Meyer, John; Boli, John; Thomas, George M. and Ramirez, Francisco O. (1997) "World Society and the Nation-State". American Journal of Sociology, 103 (1): 144-181.

Michnik, Adam and Vaclav, Havel (1993) "Justice or Revenge?" Journal of Democracy, 4: 20-27.

Ricoeur, Paul (1999) "Memory and Forgetting". In Questioning Ethics, edited by Kearney, R. and Dooley, M.. Routledge, London, 5-12.

Soysal, Yasemin (1994) Limits of Citizenship: Migrants and Postnational Membership in Europe. University of Chicago Press, Chicago.

Strauss, Leo (1955) Natural Rights and History. Chicago University Press, Chicago.

Tester, Keith (1999) "The Moral Consequentiality of Television". European Journal of Social Theory, 2 (4): 469-483.

Torpey, John (2001) "Making Whole What has Been Smashed': Reflections on Reparations". Journal of Modern History. 73: 333-358.

Turner, Bryan S. (1993) "Outline of a Theory of Human Rights". Sociology, 27 (3): 489-512.

Turner, Bryan S. (1997) "A neo-Hobbesian Theory of Human Rights: A Reply to Malcolm Waters". Sociology, 31 (3): 565-73.

Turner, Bryan S. (2006) Vulnerability and Human Rights. Penn State Press, Pennsylvania.

Waters, Malcolm (1996) "Human Rights and the Universalisation of Interests: Towards a Social Constructionist Approach". Sociology, 30 (3): 593-600. 